\title{
Penilaian Kinerja Triple Bottom Line Perusahaan High Profile dan Low Profile yang List di BEI
}

\author{
Sri Wahjuni Latifah \\ Fakultas Ekonomi dan Bisnis, Universitas Muhammadiyah Malang, Indonesia \\ Email korenpondensi: sriwahjuni@umm.ac.id
}

\begin{abstract}
This research is conducted with the aim of analyzing the performance of companies in Indonesia if measured by Triple Bottom Line and testing whether companies with high environmental risk (high profile type) have different performance with companies with low environmental risk (low profile type). Triple Bottom Line performance is measured by the GRI-G4 Index. The data were obtained from companies listed on the Indonesia Stock Exchange in 2017 and the research sample was conducted with purposive technique and obtained 42 companies. Data is obtained by downloading Financial reports and CSR Report at www.idx.co.id. Data analysis was done by descriptive statistic and Independent Sample T Test. The results showed that performance based on Triple Bottom Line in Indonesia in 2017 was low (24\%). Whereas, if observed on performance differences in companies with high profile type with low profile type, profit performance measured by economic aspects and the performance of planets measured by environmental aspects is unlikely. While the performance of people measured by social aspect shows difference between high profile company and low profile.
\end{abstract}

Keywords: Triple Bottom Line,Performace, High Profile,Low Profile

Saran Sitasi: Latifah, S. (2019). Penilaian Kinerja Triple Bottom Line Perusahaan High Profile dan Low Profile yang List di BEI. Jurnal Akuntansi dan Pajak, 20(1), 55-65. doi: http://dx.doi.org/10.29040/jap.v20i1.382

DOI: http://dx.doi.org/10.29040/jap.v20i1.382

\section{Pendahuluan}

Perusahaan dalam melaksanakan kegiatan operasinya secara langsung maupun tidak akan berintekasi dengan lingkungan. Sumber-sumber ekonomi yang digunakan perusahaan semua berasal dari masyarakat. Maka sudah seharusnya perusahaan mempertanggungjawabkan hasil pengelolaan tersebut kepada para stake holdersnya.

Di sisi lain persaingan yang ketat antara perusahaan satu dengan perusahaan lainnya dalam meraih untung sebesar besarnya memicu explorasi akan sumber daya alampun semakin tinggi tanpa memperhatikan lingkungan sekitar baik keseimbangan lingkungan, karyawan, ekosistem maupun perusahaan itu sendiri.
Dengan dikeluarkannya UU Nomor 40 Tahun 2007 tentang Perseroan Terbatas (PT) tentang ketentuan tentang pendirian PT. Pasal 74.(Untung,2008). Undang-Undang ini membahas tentang tanggung jawab sosial dan lingkungan dengan tujuan mewujudkan pembangunan ekonomi berkelanjutan guna meningkatkan kualitas kehidupan dan lingkungan yang bermanfaat bagi PT itu sendiri, komunitas setempat dan masyarakat pada umumnya. Pasal 74 tersebut menetapkan kewajiban semua perusahaan bidang sumber daya alam untuk melaksanakan tanggung jawab sosial dan lingkungan, termasuk perusahaan skala UKM. 
Hal ini menjadi suatu keharusan bagi perusahaan untuk melakukan kegiatan yang bertanggungjawab terhadap lingkungan maupun sosial atau CSR (Corporate Social Responsibility). Untuk itu perusahaan didorong untuk tidak hanya menerapkan teori single bottom line, yaitu hanya mengerjar profit, akan tetapi perusahaan dituntut untuk menerapkan Triple bottom line yaitu tidak hanya menguntungkan pihak perusahaan, tetapi juga harus menguntungkan manusia dan lingkungan sekitar. Seperti diketahui bahwa konsep Triple Bottom Line yaitu konsep yang dikembangkan oleh John Elkington pada pertengahan 1999 dalam bukunya "Canibals with Forks: the Triple Bottom Line of 21st Century Business" yang mengupas pentingnya profit, planet dan people. Bisnis yang sukses dapat diketahui dari bagian bawah laporan keuangan yang mencantumkan memperoleh keuntungan (profit), memenuhi tanggung jawab lingkungan (planet) dan memenuhi tanggung jawab sosial (people). Dalam perspektif pendekatan Triple Bottom Line perusahaan secara jelas, dipengaruhi oleh faktor internal dan eksternal. (Jackson, Boswell, \& Davis, 2011). Pada dasarnya Triple Bottom Line bisa dianggap sama dengan Corporate Social Responsibility(CSR). Konsep triple bottom line (profit, people, planet) menjadi dasar utama dalam membangun sustainability development yang bertujuan untuk memenuhi kebutuhan saat ini tanpa mengganggu kemampuan generasi berikutnya dalam memenuhi kebutuhan mereka (Latifah, 2016).

Dari segi aktivitasnya, industri pertambangan, industri manufaktur dasar dan kimia, perkebunan, dan konstruksi juga oleh European Bank For Reconstruction and Development (EBRD) disebut-sebut sebagai industri yang paling banyak merugikan masyarakat dan lingkungan sekitarnya (EBRD,2014). Untuk itu penelitian ini penting dilakukan untuk menilai kinerja perusahaan manufaktur tidak hanya dari ukuran profit, namun di ukur dengan bagaimana mengelola sumber daya alam (planet) dan bagaimana mengelola sumber daya manusia(people).

Sebagaimana berkaitan dengan tipe perusahaan berdasar risiko terhadap dampak lingkungan dikelompokan menjadi dua, yaitu: tipe high profile risk dan low profile risk.(Zuhroh \& Heri,2003). Tipe industri high profile risk pada umumnya perusahaan yang mendapat sorotan masyarakat karena aktivitas operasinya bersinggungan dengan kepentingan luas sehingga jika terjadi kelalaian dalam pengamanan proses produksi dan hasil produksi dapat berakibat fatal bagi masyarakat, contohnya adalah industri pertambangan, perkebunan dan lain-lain. Sebaliknya tipe industri low profile risk tidak mendapat sorotan masyarakat jika mengalami kelalaian dalam operasinya, sebagai contoh adalah industri perbankan.

Penelitian Zuhroh dan Heri(2003) menemukan bahwa pengungkapan tanggungjawab sosial berpengaruh pada reaksi investor di Indonesia. Dapat dikatakan bahwa reaksi investor yang diukur dengan capital gain adalah cermin perubahaan nilai perusahaan. Demikian juga Cowen $\operatorname{dkk}(1987)$ mengatakan bahwa perusahaan yang berorientasi konsumen dapat memberikan informasi pertanggungjawaban sosialnya karena dapat meningkatkan image perusahaan. Namun Kuswanto dan Latifah(2009) menemukan bahwa perusahaan tambang di Indonesia yang telah melaporkan tanggung jawabsosialnya tidak berpengaruh pada nilai perusahaan. Sedangkan Latifah(2005) menemukan bahwa perusahaan dengan tipe high risk profile memiliki kinerja sosial lebih tinggi dibanding perusahaan tipe low profil risk.

Penelitian ini dilakukan dengan tujuan mengukur kinerja perusahaan di Indonesia tidak hanya berdasar aspek keuangan tetapi juga mengukur berdasar aspek non keuangan. Berkaitan dengan pendekatan Triple Bottom Line, untuk pengukuran kinerja maka aspek keuangan adalah unsur profit, dan aspek non keuangan adalah unsur planet dan people. Kinerja perusahaan berdasar profit diukur 
berdasar kemampuan perusahaan menghasilkan laba melalui aset (Return on investment). Sedangkan kemampuan perusahaan dalam mengelola sumber daya alam dan sumber daya manusia diukur dengan aktivitas perusahaan berdasar Gobal Reporting Initiative Index (selanjutnya disingkat index GRI).

Rumusan masalah:

a. Bagaimana kinerja perusahaan di Indonesia jika diukur dengan Triple Bottom Line?

b. Apakah perusahaan yang memiliki risiko lingkungan tinggi (high profile tipe) memiliki kinerja yang berbeda dengan perusahaan yang memiliki risiko lingkungan $\operatorname{rendah}($ low profile tipe)?

\subsection{Triple Bottom Line}

Aulia dan Kartawijaya(2011), meneliti tentang Analisis Pengungkapan Triple Bottom Line dan Faktor yang Mempengaruhinya (Lintas Negara Indonesia dan Jepang). Hasil penelitiannya menunjukkan bahwa perusahaan di Jepang memberikan pengungkapan lingkungan lebih tinggi dibanding negara Indonesia. Penelitian tentang implementasi Triple Bottom Line di Indonesia juga telah dilakukan oleh Nurfajriyah (2011). Yaitu menganalisis apa saja program CSR PT. Pertamina (persero) yang sudah berjalan dan bagaimanakah implementasi konsep triple bottom line yang merupakan prinsip dasar dalam melaksanakan aktivitas CSR. Hasil penelitian menunjukkan bahwa kegiatan-kegiatan CSR yang telah dilaksanakan oleh PT. Pertamina (persero) periode 2007-2009 secara umum telah memenuhi konsep triple bottom line yang mencakup keadilan pada tiga unsur utama yaitu profit, people, dan planet. Tanggung jawab ekonomi (profit) PT. Pertamina (persero) dapat dilihat dari laba yang diperoleh pada setiap tahunnya beserta produk-produk yang senantiasa dihasilkan dari kegiatan operasional bisnisnya. Tanggung jawab lingkungan (planet) PT. Pertamina (persero) dapat dilihat dari programprogram CSR bidang lingkungan yang secara nyata dilakukan untuk menyelamatkan dan melestarikan lingkungan. Tanggung jawab sosial (people) secara nyata dilaksanakan oleh PT. Pertamina (persero) melalui aktivitas CSR bidang pendidikan, kesehatan, program kemitraan serta infrastruktur dan bencana.

\subsection{Global Reporting Initiative}

Global Reporting Initiative (GRI) adalah sebuah organisasi nirlaba yang mempromosikan keberlanjutan ekonomi. GRI menghasilkan salah satu standar dunia yang paling lazim untuk pelaporan keberlanjutan, pelaporan lingkungan sosial pemerintahan, pelaporan Triple Bottom Line (TBL), dan pelaporan Tanggung Jawab Sosial (CSR). GRI berusaha untuk membuat pelaporan keberlanjutan dengan semua organisasi sebagai suatu rutinitas dan dapat dibandingkan dengan pelaporan keuangan

Pedoman GRI secara luas digunakan oleh berbagai organisasi. Lebih dari 3.000 organisasi dan 60 negara menggunakan pedoman untuk menghasilkan laporan keberlanjutan mereka. Pedoman GRI berlaku untuk bisnis perusahaan, badan publik, perusahaan-perusahaan kecil, LSM, kelompok industri dan lainnya. GRI bertujuan untuk mengharmonisasi standar pelaporan lingkungan, misalnya audit lingkungan. Lingkungan transparansi merupakan salah satu syarat utama dari bisnis dibawah lingkup GRI. GRI mendorong peserta untuk melaporkan kinerja lingkungan mereka dengan menggunakan kriteria tertentu.

Global Reporting Initiative (GRI) mendefiniskan bahwa sustainability report merupakan pengukuran, pengungkapan dan akuntabilitas dari kinerja suatu organisasi dalam mencapai tujuan pembangunan berkelanjutan, dilaporkan kepada para pemangku kepentingan baik internal maupun eksternal. Sustainability report merupakan sebuah laporan yang dikeluarkan secara sukarela oleh perusahaan terdiri dari 3 aspek yaitu ekonomi, sosial, lingkungan. Sustainability report memperlihatkan kepedulian perusahaan terhadap pemangku kepentingan berkaitan dengan aspekaspek yang telah dilaporkan. Sesuai dengan teori stakeholder yang mengasumsikan bahwa 
eksistensi perusahaan memerlukan dukungan stakeholder, sehingga aktivitas perusahaan juga mempertimbangkan persetujuan dari stakeholder. Pengungkapan sosial dan lingkungan kemudian dipandang sebagai dialog antara perusahaan dengan stakeholders (Januarti \& Apriyanti, 2005).

\section{Tinjauan Pustaka}

Adhipradana dan Daljono (2014) melakukan penelitian tentang pengaruh kinerja keuangan, ukuran perusahaan, dan corporate governance terhadap pengungkapan sustainability report pada dua puluh lima (25) perusahaan yang mengungkapkan sustainability report dandua puluh lima (25) perusahaan yang tidak mengungkapkan sustainability report tahun 2008-2011. Hasil penelitian ini adalah adanya perbedaan antara perusahaan yang mengungkapan sustainability report dengan perusahaan yang tidak mengungkapan sustainability report.

Penelitian yang dilakukan Dahlia dan Siregar(2008) dengan sampel 77 perusahaan yang listed di BEI menemukan bahwa CSR berpengaruh pada kinerja keuangan perusahaan. Di Indonesia rata-rata pengungkapan CSR masih tergolong rendah sebagaimana penelitian Yapto, Dianne dan Rizki (2013), bahwa CSR Disclosure pada perusahaan manufaktur pada tahun 20102011 rata-rata sebesar 27,10. Hal ini diperkuat oleh Fuady (2013) dalam penelitiannya menganalisis tentang perbedaan pengungkapan triple bottom line pada perusahaan di Indonesia yang masuk dalam kategori environment high risk industry dan social high risk industry. Komponen yang digunakan dalam penelitian ini merupakan komponen yang diinstruksikan oleh GRI (Global Reporting Initiative) G3 yang mengambil sampel sebanyak 30 perusahaan baik kategori industri environment high risk dan social high risk. Hasil dari penelitian ini menunjukkan bahwa rata-rata pengungkapan triple bottom line pada environment high risk industry sebanyak 28,83 dan social high risk industry 30,20 dari 65 item. Hasil pengujian $T$ - test menunjukkan pengungkapan triple bottom line pada industri yang termasuk environment high risk dan social high risk tidak ada perbedaan yang siginikan.

Demikian juga penelitian tentang perusahaan high profile dan low profile yang dilakukan oleh Dewa dan Suryanawa(2014) menemukan bahwa CSR high profile 11,75 dan Low profile 8,52, sedangkan nilai perusahaan yang diukur dengan Tobin Q menunjukkan nilai untuk perusahaan untuk High Profile sebesar 1,28 dan perusahaan Low Profile 1,17. Lebih jauh ditemukan bahwa CSR Perusahaan High Profile dan CSR pada Low Profile berpengaruh terhadap nilai perusahaan.Sesuai dengan teori bahwa perusahaan yang mengungkapkan CSR lebih luas dapat menarik minat investor untuk berinvestasi pada perusahaan dengan demikian citra dan nilai perusahaan meningkat. Sesuai dengan teori stake holders bahwa perusahaan bukan sekedar entity namun harus mampu memberikan benefit kepada semua stakeholders.

Sedangkan temuan Latifah(2005) pada industri kategori high profile risk yang telah melaporkan tanggung jawabsosialnya memiliki kinerja sosial yang lebih tinggi dibanding perusahaan tipe low profile risk. Perusahaan go public di Indonesia memiliki kinerja keuangan yang berbeda sesuai denga tipe industrinya berkaitan dengan kewajiban lingkungannya. Sehingga rumusan hipotesis penelitian ini adalah H1: Terdapat perbedaan kinerja perusahaan kinerja ekonomi pada perusahaan high risk profile dan perusahaan Low risk Profile

$\mathrm{H} 2$ : Terdapat perbedaan kinerja perusahaan kinerja lingkungan pada perusahaan high risk profile dan perusahaan Low risk Profile

H3: Terdapat perbedaan kinerja perusahaan kinerja sosial pada perusahaan high risk profile dan perusahaan Low risk Profile

\section{Metode Penelitian}

\subsection{Data dan sampel}

Penelitian ini dilakukan pada perusahaan yang mempublikasikan Laporan CSR dan sahamnya terdaftar di Bursa efek Indonesia pada 
tahun 2017 . Sampel penelitian dilakukan dengan purposive sampling, yaitu perusahaan yang memiliki data lengkap dan perusahaan tidak mengalami rugi pada tahun 2017 sehingga sampel penelitian ini sejumlah 42 perusahaan sampel. Data penelitian diperoleh dengan cara mendownload web Idx. Variabel penelitian meliputi: kinerja profit, yang diukur dengan indikator economic dalam GRI G-4 sejumlah 13 indikator, kinerja planet diukur dengan GRI G4 index kategori lingkungan yang terdiri dari 34 indikator dan kinerja people diukur dengan GRI index kategori sosial tentang praktik ketenagakerjaan dan kenyamanan bekerja yang terdiri dari 34 indikator. Untuk menilai keseluruhan kinerja Triple Bottom Line menggunakan CSR Indeks, yaitu jumlah pengungkapan dibandingkan dengan total pengungkapan yang seharusnya, dengan rumus: $\mathrm{CSRI}_{\mathrm{j}}=\frac{\sum x i j}{n j}$, dengan penjelasan $\mathrm{CSRIj}=$ Indikator pengungkapan corporate social responsibility, $\quad \sum \mathrm{xij}=$ jumlah item yang diungkapkan perusahaan, $\mathrm{nj}=$ jumlah keseluruhan item, nj $\leq 81$. Sebelumnya dilakukan

\section{Tabel 1}

Data Kinerja Triple Bottom Line Perusahaan pada periode 2017

\begin{tabular}{|c|c|c|c|c|c|}
\hline \multirow{2}{*}{ No } & \multirow{2}{*}{ Nama Perusahaan } & \multicolumn{3}{|c|}{ Kinerja } & \multirow{2}{*}{ GPM } \\
\hline & & Ekonomi & Lingkungan & Sosial & \\
\hline 1 & AKR Corparindo & $62 \%$ & $18 \%$ & $18 \%$ & $10,20 \%$ \\
\hline 2 & Agro Lestari & $46 \%$ & $62 \%$ & $77 \%$ & $23,95 \%$ \\
\hline 3 & Astra Internasional & $23 \%$ & $29 \%$ & $18 \%$ & $21,00 \%$ \\
\hline 4 & Jasa Marga & $15 \%$ & $12 \%$ & $20 \%$ & $52,21 \%$ \\
\hline 5 & Salim Invomas & $8 \%$ & $41 \%$ & $43 \%$ & $21,60 \%$ \\
\hline 6 & Indocement tunggal prakarsa & $8 \%$ & $24 \%$ & $14 \%$ & $34,70 \%$ \\
\hline 7 & Unilever & $23 \%$ & $21 \%$ & $18 \%$ & $51,00 \%$ \\
\hline 8 & Smart & $15 \%$ & $24 \%$ & $41 \%$ & $12,20 \%$ \\
\hline 9 & Mandiri & $15 \%$ & $0 \%$ & $7 \%$ & $24,01 \%$ \\
\hline 10 & CIMB Niaga & $46 \%$ & $3 \%$ & $14 \%$ & $17,25 \%$ \\
\hline 11 & Antam & $31 \%$ & $50 \%$ & $32 \%$ & $12,99 \%$ \\
\hline 12 & Vale Indonesia & $15 \%$ & $21 \%$ & $9 \%$ & $0,90 \%$ \\
\hline 13 & BCA & $38 \%$ & $15 \%$ & $20 \%$ & $51,2 \%$ \\
\hline 14 & $\mathrm{BNI}$ & $31 \%$ & $0 \%$ & $7 \%$ & $25,88 \%$ \\
\hline 15 & BRI & $15 \%$ & $0 \%$ & $9 \%$ & $29,26 \%$ \\
\hline 16 & Indo Tambang Megah & $8 \%$ & $15 \%$ & $9 \%$ & $29,92 \%$ \\
\hline 17 & Maybank & $31 \%$ & $3 \%$ & $21 \%$ & $24,15 \%$ \\
\hline 18 & BFI & $38 \%$ & $0 \%$ & $32 \%$ & $36,79 \%$ \\
\hline 19 & Pembangunan Perumahan & $54 \%$ & $18 \%$ & $23 \%$ & $15,12 \%$ \\
\hline
\end{tabular}


Jurnal Akuntansi dan Pajak, 20(01), 2019, 60

\begin{tabular}{llcccc}
\hline \multirow{2}{*}{ No } & \multirow{2}{*}{ Nama Perusahaan } & \multicolumn{3}{c}{ Kinerja } & \multirow{2}{*}{ GPM } \\
\cline { 3 - 5 } & & Ekonomi & Lingkungan & Sosial & \\
\hline 20 & Perusahaan Gas Negara & $46 \%$ & $21 \%$ & $23 \%$ & $26,85 \%$ \\
\hline 21 & Wijaya Karya & $23 \%$ & $3 \%$ & $14 \%$ & $10,99 \%$ \\
\hline 22 & ABM Invesma & $38 \%$ & $12 \%$ & $25 \%$ & $10,50 \%$ \\
\hline 23 & Holcim, Tbk & $15 \%$ & $41 \%$ & $25 \%$ & $19,98 \%$ \\
\hline 24 & Bank Permata & $23 \%$ & $21 \%$ & $25 \%$ & $11,09 \%$ \\
\hline 25 & Sawit Sumbermas Sarana & $15 \%$ & $18 \%$ & $7 \%$ & $53,24 \%$ \\
\hline 26 & Austindo Nusantara jaya & $23 \%$ & $18 \%$ & $16 \%$ & $20,81 \%$ \\
\hline 27 & Waskita karya & $46 \%$ & $9 \%$ & $20 \%$ & $20,93 \%$ \\
\hline 28 & Wijaya Karya Beton & $46 \%$ & $12 \%$ & $20 \%$ & $10,99 \%$ \\
\hline 29 & Bukit Asam & $46 \%$ & $12 \%$ & $25 \%$ & $93,27 \%$ \\
\hline 30 & United Tractor & $62 \%$ & $15 \%$ & $25 \%$ & $22,40 \%$ \\
\hline 31 & Bumi Resources & $23 \%$ & $15 \%$ & $18 \%$ & $100 \%$ \\
\hline 32 & Petrosea & $23 \%$ & $18 \%$ & $25 \%$ & $15,75 \%$ \\
\hline 33 & Total Bangun & $62 \%$ & $21 \%$ & $30 \%$ & $17,09 \%$ \\
\hline 34 & Garuda Indonesia & $23 \%$ & $21 \%$ & $23 \%$ & $1,82 \%$ \\
\hline 35 & Timah & $69 \%$ & $32 \%$ & $43 \%$ & $17 \%$ \\
\hline 36 & Indika Energy & $15 \%$ & $9 \%$ & $9 \%$ & $11,19 \%$ \\
\hline 37 & Charoen Pokohand Food & $15 \%$ & $3 \%$ & $14 \%$ & $11,81 \%$ \\
\hline 38 & Waskita Beton Precast & $15 \%$ & $21 \%$ & $30 \%$ & $27,42 \%$ \\
\hline 39 & Semen Indonesia & $8 \%$ & $20 \%$ & $9 \%$ & $28,62 \%$ \\
\hline 40 & XL axiata & $46 \%$ & $7 \%$ & $18 \%$ & $100 \%$ \\
\hline 41 & Garuda Maintenance & $62 \%$ & $23 \%$ & $62 \%$ & $100 \%$ \\
\hline 42 & PP London Sumatera & $8 \%$ & $33 \%$ & $38 \%$ & $27,96 \%$ \\
\hline & & & & & \\
\hline
\end{tabular}

Perusahaan yang menjadi sampel penelitian ini memiliki usaha yang beragam, baik sebagai perusahaan manufaktur, perusahaan pertambangan, perhotelan bahkan perusahaan telekomunikasi. Jika dilihat dari tabel 4.2 menunjukkan hasil kinerja perusahaan beragam. Seperti kinerja ekonomi maka PT.Timah memiliki kinerja ekonomi paling tinggi. Sedangkan jika dilihat dari kinerja lingkungan

\subsection{Pembahasan}

\subsubsection{Analisis Statistik Diskriptif}

Tabel 2

Hasil Statistik Diskriptif

\begin{tabular}{|c|c|c|c|c|c|}
\hline & & Ekonomi & Lingkungan & Sosial & GPM \\
\hline \multirow[t]{2}{*}{$\overline{\mathrm{N}}$} & Valid & 42 & 42 & 42 & 42 \\
\hline & Missing & 0 & 0 & 0 & 0 \\
\hline \multicolumn{2}{|c|}{ Mean } & ,3040293 &, 1876212 & ,2251401 & 2670 \\
\hline \multicolumn{2}{|c|}{ Median } & ,2307692 &, 1764706 &, 2045455 & ,2097 \\
\hline \multicolumn{2}{|c|}{ Std. Deviation } & 17895673 & , 14966566 & 13457418 & 21532 \\
\hline \multicolumn{2}{|c|}{ Minimum } & ,07692 & ,00000 & ,06818 &, 01 \\
\hline \multicolumn{2}{|c|}{ Maximum } & ,69231 & ,61765 & ,77273 & 1,00 \\
\hline
\end{tabular}

maka PT. Agro Lestari paling tinggi dan jika dilihat dari kinerja sosial juga PT.Agro Lestari memiliki kinerja sosial paling tinggi. Namun tidak demikian halnya dengan kemampuan perusahaan dalam menghasilkan laba kotor dari penjualan justru PT. XL Axiata, Bumi Resources dan PT.Garuda Indonesia memiliki nilai GPM paling besar. 
Kinerja perusahaan yang diukur dengan konsep Triple Bottom Line yaitu mengukur kinerja tidak hanya berdasar nilai ekonomi namun diukur dengan kinerja lingkungan dan sosial. Aktivitas perusahaan berdasar aspek tersebut dilaporkan dalam sebuah Laporan Sustainbility atau Laporan Corporate Social Responsibility. Penelitian tentang kinerja berdasar Triple Bottom Line pada perusahaan di Indonesia menunjukkan kinerja yang masih rendah karena rata-rata perusahaan memiliki kinerja sebesar $24 \%$. Artinya dari 81 item yang harus dilakukan dan dilaporkan berdasar ketentuan GRI, ternyata perusahaan baru melakukannya sebesar 19 item. Seperti temuan penelitian Raharjo dan Djanuarti (2014) rata-rata indeks pengungkapan CSR berdasar GRI pada perusahaan di Indonesia pada tahun 2008 -2011 adalah rendah yaitu sebesar sepuluh persen(10\%). Dengan demikian sudah kenaikan pada tahun 2017 dibanding tahun 2011.

Hal ini didukung dengan penelitian Suherman (2011) bahwa Kesuksesan Program CSR dapat memiliki dampak positif untuk meningkatkan citra perusahaan jika dilakukan secara kontinyu, terukur, dikelola dengan baik, berorientasi internal dan eksternal.

Berdasarkan tabel 2 dapat diamati bahwa kinerja ekonomi yang diungkapkan oleh perusahaan rata-rata sebesar $30,04 \%$ dan hal ini masih tergolong rendah dari yang seharusnya $100 \%$. Demikian juga kinerja lingkungan ratarata hanya sebesar $18,76 \%$ dan kinerja sosial rata-rata sebesar $22,57 \%$ hal ini juga termasuk memiliki kinerja yang rendah. Jika diamati dari kemampuan perusahaan dalam menghasilkan laba kotor dari penjualan atau gross profit margin cukup besar yaitu $26,7 \%$ atau dapat dikatakan perusahaan sudah efisien dalam memperoleh laba dari penjualan.
Kinerja Triple Bottom Line

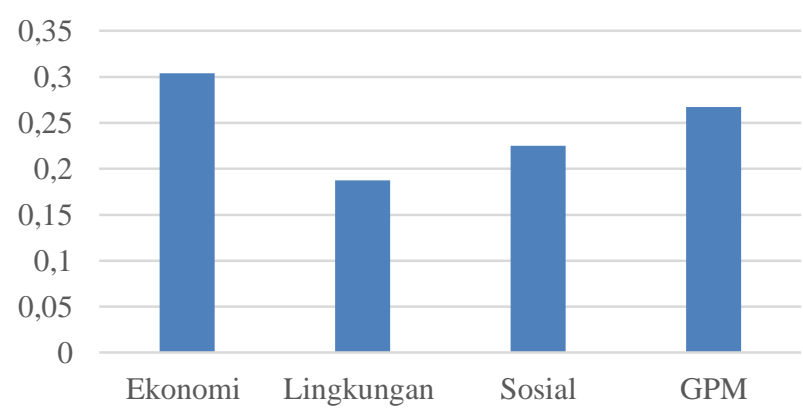

Gambar 1: Rata-rata Kinerja Triple Bottom Line Sampel

Berdasar gambar 1 di atas dapat dilihat bahwa dari ke-empat ukuran kinerja maka kinerja ekonomi paling tinggi dibanding yang lain. Hal ini juga di dukung oleh tingkat gross profit margin juga tinggi. Namun kinerja lingkungan termasuk paling rendah jika dibanding kinerja ekonomi dan sosial. Dengan demikian dapat dikatakan bahwa perusahaan sampel lebih dominan memperhatikan kinerja ekonomi dan pencapaian profit yang tinggi dibandingkan dengan meperhatikan aspek lingkungan maupun sosial.

\subsubsection{Perbandingan Kinerja Perusahaan Low Profile dan High Profile}

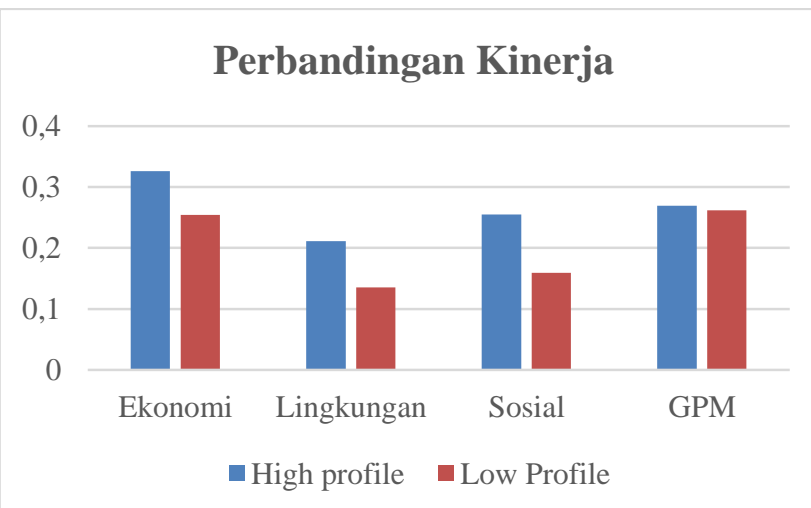

Gambar 2: Perbandingan Kinerja Perusahaan High Profile dengan Low Profile

Jika di amati lebih jauh tentang perbandingan kinerja perusahaan tipe high profile dan low profile, maka dapat dikatakan bahwa kinerja ekonomi perusahaan high profile lebih tinggi dibanding kinerja ekonomi perusahaan low profile. Demikian juga kinerja lingkungan perusahaan high profile lebih tinggi 
dibanding perusahaan low profile. Kinerja sosial perusahaan high profile juga lebih tinggi dibanding kinerja kinerja sosial perusahaan low profile. Namun gross profit margin perusahaan high profile dan low profile nampak sama atau tidak berbeda.

\subsubsection{Uji hipotesis}

\section{H1: Uji Beda Kinerja Ekonomi}

Kinerja ekonomi di ukur dengan indikator ekonomi dalam GRI G-4. Berikut hasil uji beda kinerja ekonomi perusahaan high profile dan low profile.

Tabel 3

Uji Beda Kinerja Ekonomi

\begin{tabular}{|c|c|c|c|c|c|c|}
\hline & & \multicolumn{2}{|c|}{$\begin{array}{c}\text { Levene's Test for Equality of } \\
\text { Variances } \\
\end{array}$} & \multicolumn{3}{|c|}{ t-test for Equality of Means } \\
\hline & & $\mathbf{F}$ & Sig. & $\mathbf{t}$ & Df & Sig. (2-tailed) \\
\hline \multirow[t]{2}{*}{$\overline{\mathrm{Ec}}$} & Equal variances assumed & 3,796 &, 058 & 1,209 & 40 & ,234 \\
\hline & Equal variances not assumed & & & 1,370 & 31,664 & 180 \\
\hline
\end{tabular}

Berdasar tabel 3 dapat ditemukan bahwa kinerja ekonomi perusahaan high profile tidak berbeda dengan kinerja ekonomi perusahaan low profile atau dapat dikatakan bahwa $\mathrm{H} 1$ penelitian ini tidak berhasil diterima. Hal ini diperkuat dengan data bahwa jumlah pengungkapan ekonomi yang merupakan indikator kinerja ekonomi perusahaan high profile sebesar $32,62 \%$ dan perusahaan tipe low profile sebesar $25,44 \%$.
Jika diamati lebih jauh maka perusahaan dengan tipe high profile lebih banyak mengungkapkan tentang nilai ekonomi langsung yang dihasilkan dan didistribusikan, keberadaan pasar dan dampak ekonomi tidak langsung. Sedangkan perusahaan tipe low profile lebih banyak mengungkapkan tentang nilai ekonomi langsung yang dihasilkan dan didistribusikan, praktik pengadaan dan dampak ekonomi tidak langsung.

Tabel 4

Uji Beda Gross Profit Margin

\begin{tabular}{|c|c|c|c|c|c|c|c|}
\hline & & \multicolumn{3}{|c|}{$\begin{array}{c}\text { Levene's Test for Equality of } \\
\text { Variances } \\
\end{array}$} & \multicolumn{3}{|c|}{ t-test for Equality of Means } \\
\hline & & $\mathbf{F}$ & Sig. & & $\mathbf{T}$ & Df & Sig. (2-tailed) \\
\hline \multirow[t]{2}{*}{$\overline{\text { GPM }}$} & Equal variances assumed & 2,102 & & $\overline{155}$ & , 107 & 40 & ,915 \\
\hline & $\begin{array}{l}\text { Equal variances not } \\
\text { assumed }\end{array}$ & & & &, 134 & 38,411 & ,894 \\
\hline
\end{tabular}

Demikian juga kemampuan perusahaan dalam menghasilkan Gross Profit Margin antara perusahaan high profile dan low profile adalah sama atau tidak berbeda secara statistik. Hal ini didukung dengan temuan bahwa rata-rata GPM perusahaan High Profile sebesar 26,94\% dan rata-rata GPM perusahaan Low Profile sebesar 26,19\%. Gross profit margin merupakan ukuran kemampuan perusahaan dalam memperoleh laba kotor dari penjualan. Hasil penelitian ini menunjukkan bahwa semua perusahaan baik tipe high profile maupun low profile akan mementingkan kemampuan dalam memperoleh laba kotor untuk mendukung keberlanjutan perusahaan. Laba dapat menjadi faktor penentu nilai perusahaan sebagaimana hasil penelitian Ira(2014) memberikan bukti bahwa CSR dimoderasi laba berdasar aset berpengaruh pada nilai perusahaan.

\section{H2: Uji Beda Kinerja Planet}

Kinerja triple Bottom Line berdasar aspek planet disebut juga kinerja berdasar lingkungan. Berikut hasil uji beda kinerja lingkungan perusahaan tipe high profile dan low profile: 
Tabel 5

Uji Beda Kinerja Lingkungan

\begin{tabular}{|c|c|c|c|c|c|c|}
\hline & & \multicolumn{2}{|c|}{$\begin{array}{c}\text { Levene's Test for Equality of } \\
\text { Variances } \\
\end{array}$} & \multicolumn{3}{|c|}{ t-test for Equality of Means } \\
\hline & & $\mathbf{F}$ & Sig. & $\mathbf{t}$ & df & Sig. (2-tailed) \\
\hline \multirow[t]{2}{*}{ Env } & Equal variances assumed & 3,408 &, 072 & 1,534 & 40 &, 133 \\
\hline & Equal variances not assumed & & & 1,308 & 16,765 & 208 \\
\hline
\end{tabular}

Berdasar tabel 5 dapat dikatakan bahwa kinerja lingkungan perusahaan tipe high profile tidak berbeda dengan kinerja lingkungan pada perusahaan tipe low profile. Dengan demikian $\mathrm{H} 2$ tidak berhasil diterima. Hal ini didukung dengan data penelitian ini yang menunjukkan bahwa perusahaan high profile lebih banyak mengungkapkan tentang material, energy, air dan kepatuhan terhadap lingkungan, demikian juga perusahaan low profile lebih banyak mengungkapkan tentang material dan energy. Hasil ini memberikan bukti bahwa perusahaan di Indonesia telah mematuhi peraturan lingkungan sesuai GRI, tidak menjadi memandang apakah perusahaan yang lebih tinggi risiko lingkungan (high profile) atau perusahaan yang risiko lingkungannya rendah (low profile). Namun selama ini perusahaan masih fokus pada energi, belum banyak perusahaan yang melakukan aktivitas lingkungan berkaitan dengan emisi dan air limbah. Seharusnya perusahaan tipe high profile juga melakukan aktivitas berkaitan dengan emisi dan air limbah, namun faktanya hanya ada beberapa saja perusahaan yang menerapkan, sebagai contoh adalah perusahaan Austindo Nusantara hanya melakukan pengelolaan emisi, dan Perusahaan Sawit Sumbermas hanya melakukan pengelolaan air limbah. Bahkan ada banyak perusahaan yang tidak memperhatikan pengelolaan emisi dan limbah padahal termasuk kategori tipe perusahaan high profile, sebagai contoh yaitu Indika Energy, Wijaya Karya dan ABM Investama. Hal ini memperkuat temuan Suherman(2011), yang menyatakan bahwa kesuksesan Program CSR dapat memiliki dampak positif untuk meningkatkan citra perusahaan jika dilakukan secara kontinyu, terukur, dikelola dengan baik, berorientasi internal dan eksternal.

\section{H3:Uji Beda Kinerja People.}

Kinerja aspek people diukur dengan Sosial. Berikut hasil perbedaan kinerja sosial sebagaimana pada tabel 6 di bawah ini:

Tabel 6

Uji Beda Kinerja Sosial

\begin{tabular}{|c|c|c|c|c|c|c|}
\hline & & \multicolumn{2}{|c|}{$\begin{array}{c}\text { Levene's Test for Equality of } \\
\text { Variances } \\
\end{array}$} & \multicolumn{3}{|c|}{ t-test for Equality of Means } \\
\hline & & $\mathrm{F}$ & Sig. & $\mathrm{t}$ & Df & Sig. (2-tailed) \\
\hline \multirow[t]{2}{*}{ Sos } & Equal variances assumed & 1,182 & 284 & 2,227 & 40 &, 032 \\
\hline & Equal variances not assumed & & & 2,739 & 37,848 & 009 \\
\hline
\end{tabular}

Berdasar tabel 6 dapat ditemukan bahwa kinerja sosial perusahaan tipe high profile berbeda dengan kinerja sosial perusahaan tipe low profile. Dengan demikian $\mathrm{H} 3$ berhasil diterima. Hal ini di dukung dengan nilai ratarata pengungkapan kinerja sosial perusahaan high profile sebesar $25,47 \%$ sedangkan perusahaan low profile sebesar 15,91\%. Perbedaan tersebut diantaranya adalah perusahaan tipe high profile seperti PT.Wijaya karya, Wijaya Beton, Antam dan lain-laninya lebih fokus pada kepegawaian, kesehatan dan keselamatan kerja, non diskriminasi, kebebasan berserikat dan perlindungan kolektif, masyarakat 
lokal dan privasi pelanggan. Sedangkan perusahaan tipe low profile seperti Bank Mandiri, BCA, BFI memfokuskan pada aspek kepegawaian, pelatihan dan pendidikan serta privasi pelanggan.

Seperti halnya penenelitian Burhan dan Rahmanti(2012) menemukan bahwa dampak Sustainbility Report mempengaruhi kinerja perusahaan yang listing di BEI tahun 2006 -2009. Kinerja perusahaan diukur dengan Return On Aset. Sedangan Sustainbility Report diukur dengan Disclosure Indeks GRI. Lebih jauh ditemukan hanya kinerja sosial yang mempengaruhi kinerja perusahaan.

\section{Kesimpulan}

Berdasar analisis data dengan tehnik statistik diskriptif dan uji beda Independen Sample T Tes maka dapat disimpulkan bahwa kinerja perusahaan di Indonesia jika diukur dengan Triple Bottom Line tergolong rendah karena ratarata perusahaan hanya melakukan sebesar $24 \%$ dari yang seharusnya dilakukan. Sedangkan jika diamati tentang perbedaan kinerja pada perusahaan yang memiliki risiko lingkungan tinggi (high profile tipe) dengan perusahaan yang memiliki risiko lingkungan rendah(low profile tipe) dapat dijabarkan sebagai berikut. Kinerja profit yang diukur dengan aspek ekonomi menunjukkan tidak berbeda antara perusahaan tipe high profile maupun low profile. Kinerja planet yang diukur dengan aspek lingkungan juga tidak berbeda, namun kinerja people yang diukur dengan aspek sosial menunjukkan perbedaan antara perusahaan high profile dengan low profile.

Penelitian ini terbatas pada satu periode penelitian saja yaitu tahun 2017, untuk itu penelitian berikutnya dapat memperpanjang periode penelitian sehingga sampel penelitian dapat lebih banyak dan dapat memperoleh hasil yang lebih baik. Hasil penelitian ini dapat bermanfaat untuk pengambil keputusan investasi bahwa perusahaan di Indonesia masih sedikit yang memperhatikan aspek keberlanjutan, sehingga hal ini menjadi sebuah pertimbangan dalam keputusan investasi. Sedangkan untuk manajemen sebaiknya mulai memperhatikan bahwa keberlanjutan perusahaan tidak hanya ditentukan oleh kinerja ekonomi, namun juga ditentukan kinerja lingkungan dan kinerja sosial.

\section{Ucapan Terimakasih}

Dengan terselesainya penelitian ini kami sampaikan terimakasih yang sebesar-besarnya kepada Rektor Universitas Muhammadiyah Malang, Dekan Fakultas Ekonomi \& Bisnis, beserta jajarannya yang telah memberikan dana kegiatan ini sehingga dapat selesai dengan lancar dan tak kurang satu apapun. Terimakasih juga untuk Anissa $\mathrm{R}$ yang telah membantu pengumpulan data dan membantu pengumpulan referensi serta membantu analisis data.

\section{Daftar Pustaka}

Adhipradana, F., dan Daljono.(2014). "Pengaruh Kinerja Keuangan, Ukuran Perusahaan, dan Coporate Governance Terhadap Pengungkapan Sustainability Report". Diponegoro Journal Of Accounting, 3( 1),112.

Aulia,Sandra Z dan Kartawijaya(2011). AnalisPengungkapan Triple Bottom Line danFaktor yang mempengaruhi:Lintas Negara Indonesia dan Jepang. Prosiding Simposium Nasional Akuntansi XIV Aceh, 302-309

Cowen S.S., Ferreeri, L.B. and parker,L.D(1987).The Impact of Corporate Charactersistic On Social Responsibility Disclosure: A Typolofy and FrequencyBased Analysis,"Accounting, Organizations and Society, 12(2), 111- 122

Dewa, Made Bagus Umbara dan Suryanawa, I Ketut(2014). Pengungkapan Tanggungjawab Sosial pada nilai perusahaan. E-jurnal Akuntansi Universitas Udayana 9(2), 410424

EBRD(2014). European Bank For Rescontruction and Development. EBRD Environment and Social Risk Categorisation List.http://www.adb.org/sites/default/files/lin ked-documents/45230-001-arm-esms.pdf 
Fuady, Tsamrotul(2013). Analisis Praktek Pengungkapan Triple Bottom Line pada Annual Report Perusahaan.Skripsi UMM

GRI. (2013). "Reporting Principles and Standard Disclosures". Amsterdam, Netherlands.

Jackson, A., Boswell, K., \& Davis, D. (2011). Sustainability and Triple Bottom Line Reporting--What is It all About? International Business, Humanities and Technology, 1(3), 55-59.

Januarti, I., \& Apriyanti, D(2005), Pengaruh Tanggung Jawab Sosial Perusahaan terhadap Kinerja Keuangan. Jurnal Manajemen, Akuntansi, dan Sistem Informasi. 5, 227-243.

Kuswanto, Yeni dan Latifah, Sri Wahjuni (2009).

Corporate Social Disclosure dan Kinerjayang di ukur dengan Economic Value Added Pada Perusahaan Pertambangan di BEI,Skripsi UMM

Latifah,Sri Wahjuni(2005). Analisis Kinerja Keuangan, Kinerja Sosial, dan Pengungkapan Tanggung Jawab Sosial Perusahaan High Profile dan Low Profile. Jurnal Media Ekonomi UMM,15(24).

Latifah, S. W. (2016). Sustainability Report, Tinjauan Sekilas! Ekuitas "Majalah Mahasiswa Akuntansi" UMM ,9(1),45-48
Nurfajriyah (2011).Implementasi Konsep Triple Bottom Line pada PT. Pertamina Persero). Thesis. UIN Sunan Kalijaga Yogyakarta.

Raharjo,Arif dan Djanuarti,Indra (2014). Pengaruh Tanggungjawab Sosial Perusahaan terhadap Nilai perusahaan Studi Kasus pada Perusahaan Pertambangan Yang Terdaftar di BEI 2008 - 2012. Diponegoro Journal of Accounting,3(1), 1-10

Suherman,Kusniadji(2011).Mengkomunikasikan Program CSR untuk Meningkatkan Citra Perusahaan.Jurnal Komunikasi Universitas Tarumanegara,3( 01)

Yapto,Marissa , Dianne Frisko K, Rizki (2013). Pengaruh Tanggung Jawab Sosial Perusahaan Terhadap Nilai Perusahaan Studi Kasus pada perusahaan Manufaktur yang Terdaftar di BEI periode 2010 2011.Calyptra Jurnal.2(1)

Zuhroh,Diana dan Heri,I Putu Pande(2003) Analisis Pengaruh Luas Pengungkapan Sosial dalam Laporan Tahunan Perusahaan terhadap Reaksi Insvetor(Studi Kasus pada Perusahaan-perusahaan High Profile di BEJ). Prosiding SNA VI.Surabaya, 145-152 